\title{
NÁBOŽENSKÁ SVOBODA V KONTEXTU TEORIE JOHNA FINNISE
}

\section{RELIGIOUS LIBERTY IN THE CONTEXT OF THE THEORY OF JOHN FINNIS}

\author{
Petr Osina \\ Právnická fakulta Univerzity Palackého v Olomouci
}

https://doi.org/10.33542/SIC2019-1-03

\begin{abstract}
ABSTRAKT
Článek se věnuje analýze role náboženství v přirozenoprávní koncepci právního teoretika Johna Finnise. Na začátku se zabývá vymezením významu náboženství v souvislosti se smyslem lidské existence $v$ díle Finnisova kolegy a spolupracovníka Germaina Griseze. Na to navazuje Finnisova charakteristika důležitosti náboženské svobody a zároveň polemika s egalitárními teoriemi náboženské svobody. Finnis vycházi jednoznačně z židovsko-křest’anského pojetí, což může být problematické z hlediska možného zpochybnění rovnosti náboženství. V závěru je pak analyzován názor Johna Finnise na vymezeni hranic náboženské svobody v souvislosti s islamistickým terorismem.
\end{abstract}

\begin{abstract}
The article deals with the analysis of the role of religion in natural law theory of John Finnis. At the beginning it concentrates on the description of the importance of religion in the context of the meaning of human existence in the work of Finnis's colleague Germain Grisez. The article continues with Finnis's description of the importance of religious freedom and discussion with egalitarian theories of religious freedom. Finnis proceeds from Judeo-Christian conception which may by problematic from the point of view of possible challenging of the equality of religions. Opinions of John Finnis on the description of borders of religious freedom in the context of Islamic terrorism are analyzed at the end of the article.
\end{abstract}

\section{I. ÚVOD}

Na základě inspirace v koncepci Tomáše Akvinského John Finnis tvrdí, že existuje sedm základních hodnot, které mohou být objektivně ustanoveny. Jsou jimi život, vědění, hra, estetický zážitek, sociabilita (přátelství), praktický rozum a „náboženství“. Uvozovky, do nichž dává Finnis výraz „náboženství“, signalizují, že užívá tento pojem v širším významu, než jaký mu dávají religionisté. „Náboženství“v pojetí Finnise vyjadřuje lidskou touhu a potřebu vykročení za hranice vlastního života a hranice vesmíru - díky kladení existenciálních otázek a hledání odpovědí na ně. ${ }^{1}$

\section{NÁBOŽENSTVÍ A MORÁLNÍ ŽIVOT}

Existence všeho, co známe nebo si dokážeme představit, je závislá na naplnění podmínky, spočívající v existenci základní příčiny všech věcí. Bůh jako tvůrce je naprosto záhadný, není

FINNIS, J. Natural Law and Natural Rights, Oxford: Oxford University Press, 1980, s. 89. 
tělesem, hmotou ani energií, není vymezitelný v prostoru nebo v čase, božská neměnnost nezahrnuje stabilitu, setrvačnost nebo nezměnitelnost. Naše vědomí je významné v tom, že se v něm projevuje princip praktického rozumu a člověk rozumně postuluje mnoho příčin, které není ani schopen spočítat.

Finnisův kolega a spolupracovník Germain Grisez poukazuje na jedné straně na uvědomění si, že zdroj direktiv přirozeného práva je nutné bytí a zdroj existence všeho kolem nás je záhadný. Na druhé straně jestliže uvažujeme o stvořiteli jako inteligentním a laskavém, je třeba považovat realitu světa okolo nás za dar. Identifikací tohoto zdroje podmíněné existence v rámci zdroje přirozeného práva lépe porozumíme tomu, jak jsou lidské bytosti svázány s mimolidským zdrojem hodnot a smyslu lidské existence. Harmonie ve vztahu s Bohem by měla být zachována a prohlubována. ${ }^{2}$

Existuje určitá hierarchie hodnot. Každá základní lidská hodnota je nadřazena každé pomocné hodnotě a všemu, co lze považovat za objekt emocionální touhy. Základní lidské hodnoty jsou neredukovatelné a týkají se různých kategorií, tím pádem se jedná o hodnoty realizované $\mathrm{v}$ různých záležitostech. Někdy morální závazky limitují priority člověka v povinnosti objevovat různé druhy základních hodnot a člověk si v takovém prŕípadě vybere nejvíce morálně akceptovatelnou alternativu. Nesouměřitelnost základních hodnot z různých kategorií naznačuje, že člověk nemůže organizovat svůj dosavadní život z pohledu budoucí realizace základních hodnot, jako je život nebo pravda. ${ }^{3}$

Morálně poctiví lidé vždy hledají způsoby, jak se vyhnout nemorálnosti při realizaci základních hodnot. Harmonie s jinými lidmi není v sázce při každé volbě, kterou člověk dělá a harmonie uvnitř každého člověka je v sázce pouze tehdy, když existuje jedna nebo více přitažlivějších možností, které jsou morálně neakceptovatelné - tedy hodnota náboženství může být v sázce při každé volbě. Hlavním účelem je udržovat a podporovat harmonii s Bohem v pokračujícím spolupracujícím vztahu. Harmonie s Bohem je samožrejmým dobrem a následování jeho vedení udržuje a podporuje tuto harmonii. Bůh vede jednotlivce i komunity směrem k dosažení jejich vlastního dobra. ${ }^{4}$

Člověk tedy musí neustále spolupracovat s Bohem, který zásady praktického rozumu vepsal do lidských srdcí. Ale Bůh nevede všechny lidské bytosti pouze podle principů praktického rozumu, vede také každou osobu v jednotlivých unikátních situacích. Každá osoba má specifické schopnosti, které umožňují uskutečnit morálně akceptovatelné volby. Lidský život může být integrovaným celkem, pokud člověk důsledně jedná v souladu s božím vedením. Bůh vede různé jednotlivce $\mathrm{k}$ využití jejich osobních daností, což se projevuje v rozdílném zorganizování života každého člověka a zajištění jeho individuálních potřeb. ${ }^{5}$

Racionalizace brání spoustě lidem v pochopení relevantních pravd. Člověk se brání tomu, aby byl veden neviditelnou silou, se kterou má navíc spolupracovat. Posléze je možné vidět snahu Bohem manipulovat a přisoudit mu lidské vlastnosti, což může vést k polyteismu nebo lidským obětem. Aby pak lidé věděli, co mají dělat, uchylují se k věštění budoucnosti. Rozdělení lidí do vzájemně konfliktních komunit vede k vytváření vlastních bohů, náboženství a morálních kodexů.

2 GRISEZ, G. Natural Law, God, Religion and Human Fulfillment, American Journal of Jurisprudence, Vol. 46, 2001, s. 14.

Tamtéž, s. 15.

Tamtéž, s. 16.

Tamtéž, s. 17. 
Bůh je jednak mysteriózní stvořitel neovlivnitelný lidmi, jednak prozřetelný Hospodin vedoucí lidi k tomu, co je jim prospěšné. Přehlížení Božského vedení a narušení harmonie s Bohem způsobí, že lidé ztratí soulad s ostatními a se sebou samým. Lidský rozkvět a dobrý život závisí na Boží pomoci a věrnosti lidí tomuto Bohu. ${ }^{6}$

Grisezovo pojetí nebe a cesty k němu má primárně sociální až politický charakter. Smysl pozemského života vidí ve vybudování Božího království. Přestože toto království může začít fungovat až v momentu druhého příchodu Ježíše Krista, věřící mohou přispět k jeho budování už tady a ted'. Ve skutečnosti totiž každé morálně přijatelné jednání přispívá k vytváření tohoto království. Teorie, která vidí morálku jako kritérium pro identifikaci jednání, které přispívá $\mathrm{k}$ budování Božího království, přirozeně chápe odlišně roli morálních principů ve srovnání s teorií, která vidí morálku jako formu terapie pro nemocnou duši. ${ }^{7}$

\section{NÁBOŽENSTVÍ JAKO HLEDÁNÍ SMYSLU ŽIVOTA}

„Náboženství“ představuje samo schopnost kladení si existenciálních otázek. Jeho základní hodnota je pocit’ována také agnostiky a dokonce ateisty, kteří otázky o existenci Boha či smyslu lidského života řeší negativně nebo je ponechávají bez odpovědi. ${ }^{8}$ Charakteristickým znakem „nové teorie přirozeného práva“ je to, že „náboženství“ nepředstavuje výchozí bod celé teorie a nemusí být chápáno jako nezbytný předpoklad teorie přirozeného práva.

Stát má především prostřednictvím právního řádu zaručit náboženskou svobodu. Tato svoboda má být všem přiznána ve stejné míře, což vyžaduje princip férovosti, tedy zákazu svévolné preference osob. ${ }^{9}$ Protože je náboženství zpravidla jevem kolektivním, je třeba tuto svobodu poskytnout nejen pro individuální jednání, ale také pro jednání uskutečňované společně s jinými lidmi. Hodnota náboženství odůvodňuje právo na náboženskou svobodu a tomu odpovídající povinnost veřejné moci nikoliv pouze zdržet se donucování lidí na základě teologických výhrad k jejich náboženské víře a praktikám, ale také chránit jedince a náboženská společenství před jinými, kteří by vůči nim takové donucení uplatňovali. ${ }^{10}$

Církvím má být poskytnuta svoboda jednat navenek v souladu s náboženskou vírou. Stát je povinen zajistit církvím svobodu veřejně hlásat svoji víru, vykonávat kult, pomáhat svým členům při prožívání náboženského života nebo jiným způsobem projevovat navenek kolektivní formou víru. Tato svoboda však nutně předpokládá svobodu v uspořádání vnitřních vztahů. ${ }^{11}$

Vedlejší argument pro požadavek maximalizace náboženské svobody lze odvodit z účelu politické společnosti. Jedná se o společnost přirozenou, s účelem ležícím v přirozeném řádu a $\mathrm{v}$ tomto čase. $Z$ tohoto důvodu státu principiálně nepř́isluší zásahy do lidského úsilí o dosažení hodnot v řádu věčném a nadpřirozeném (jako je spása člověka), samozřejmě při respektování mezí této zásady vyplývajících z požadavků obecného dobra. ${ }^{12}$

Náboženství podle Finnise zahrnuje otázky spojené s konečnými příčinami existence světa a místa člověka v něm a zároveň různé způsoby jejich řešení. Náboženský charakter mají například následující otázky: Jak se směřování lidského života vztahuje k věčnému řádu vesmíru a prrípadného pramene tohoto řádu? Není lidská svoboda určitým způsobem podřízena něčemu

\footnotetext{
GRISEZ, G. Natural Law, God, Religion and Human Fulfillment, American Journal of Jurisprudence, Vol. 46, 2001, s. 21.

7 KAVENY, C. Ethics at the Edges of Law: Christian Moralists and American Legal Thought, New York: Oxford University Press, 2017, s. 228.

8 FINNIS, J. Natural Law and Natural Rights, Oxford: Oxford University Press, 1980, s. 90.

9 GRISEZ, G., BOYLE, J., FINNIS, J.: Practical Principles, Moral Truth and Ultimate Ends, The American Journal of Jurisprudence, Vol. 32, 1987, s. 128.

10 GEORGE, R. In Defence of Natural Law, New York: Oxford University Press, 2004, s. 134.

11 KŘÍŽ, J. Autonomie cirkví, Praha: C. H. Beck, 2017, s. 31.

12 FINNIS, J. Religion and Public Reason, New York: Oxford University Press, 2011, s. 92.
} 
jinému, co umožňuje existenci této svobody, lidského intelektu a lidské moci a co je svobodné, inteligentní a suverénní v rozsahu, ve kterém žádná lidská bytost být nemůže? ${ }^{13}$

Mnoho osob zpochybňuje náboženství a jeho zařazení mezi základní hodnoty, ale Finnis toto zařazení obhajuje. Podle něj nejde o konkrétní odpovědi, ale o to, aby otázky týkající se vesmírného řádu, lidské svobody a rozumu byly promýšleny racionálním způsobem a ve shodě s pravdou, nezávisle na tom k jakým odpovědím dojdeme, dokonce i kdyby se ukázaly agnostické nebo negativní.

Jde tudíž o důležitost otázek tohoto typu a samotnou možnost jejich kladení, jelikož zákaz jejich kladení omezuje určité dimenze lidskosti. Tyto dimenze se podle Finnise dotýkají každého a i takový zastánce ateismu jako byl Jean Paul Sartre je musel nějakým způsobem zažít, jelikož zastával názor, že člověk má závazek jednat svobodně a autenticky a usilovat o stejnou svobodu pro ostatní lidi. Takové vymezení problému ale směřuje úvahy za horizont čistě lidské reality. Proto v debatě o náboženství jde o to, abychom vykročili za tento horizont. Podle Finnise se naše pojetí odpovědnosti za to, co jsme a co chceme dělat, neomezuje pouze na starost o život, zábavu, rozmnožování, vztahy s jinými nebo rozumnost. ${ }^{14}$

\section{NÁBOŽENSKÁ SVOBODA}

Zdůvodnění místa nadkonfesně pojímaného náboženství mezi základními hodnotami představuje dobrý výchozí bod pro úvahy o náboženské svobodě. Ve Finnisově pojetí představují polemiku s tzv. egalitárními teoriemi náboženské svobody v podání Ronalda Dworkina, Christophera Eisgrubera a Lawrence Sagera.

Finnis vychází z deklarace o náboženské svobodě Dignitatis humanae, což je dokument, který vznikl během Druhého vatikánského koncilu a vyhlášen byl papežem Pavlem VI. v prosinci 1965. Shodně s deklarací vymezuje náboženskou svobodu jako „imunitu“, to znamená nárok na to, aby člověk nebyl předmětem nátlaku v rámci výkonu individuálních nebo kolektivních náboženských úkonů.

Podstatou náboženské svobody je povinnost státu a jeho orgánů, stejně jako všech členů společnosti nezasahovat do výkonu náboženských aktů, pokud neohrožují práva jiných, veřejný pořádek nebo veřejnou morálku. Kličcvý význam v rámci náboženské svobody má povinnost hledat pravdu a z toho odvozený závazek směřovat svůj život v souladu s touto pravdou. Tento závazek může být naplněn jedině za podmínky autentičnosti, která může existovat jedině v situaci chybějícího nátlaku. ${ }^{15}$

Finnis souhlasí s argumentací Christophera Eisgrubera a Lawrence Sagera v rámci toho, kdy oba podporují doktrínu „oddělující zdi“ mezi státem a církvemi a také interpretaci Nejvyššího soudu USA ve vztahu k ústavní klauzuli, která vylučuje pomoc státu náboženským organizacím. Neshoduje se s nimi ale v názoru, že náboženství a náboženská svoboda nemají žádný morální a ústavní status odlišný od jiných „hlubokých přesvědčeni““. ${ }^{16}$

Podle Eisgrubera a Sagera mají náboženské akty stejný význam jako vztahy, aktivity a touhy, jejichž motivace jsou hluboké a svědčí o zásadních volbách člověka. ${ }^{17}$ Finnis v tom vidí zpochybnění kolektivního pojetí náboženské svobody, které se projevuje v autonomii církví a náboženských společností. Pokud by náboženství bylo jen jedním z hlubokých pocitů a aktivit, které působí na člověka a projevují se v jeho konání, nezasluhovalo by zvláštní ústavní ochranu.

\footnotetext{
FINNIS, J. Natural Law and Natural Rights, Oxford: Oxford University Press, 1980, s. 89.

4 FINNIS, J. Natural Law and Natural Rights, Oxford: Oxford University Press, 1980, s. 90.

15 FINNIS, J. Why Religious Liberty is a Special, Important and Limited Right. Notre Dame Legal Studies Paper No. 09-11, 2008, s. 3.

16 Tamtéž, s. 4.

17 EISGRUBER, Ch., SAGER, L. Religious Freedom and the Constitution, Harvard University Press, 2007, s. 65.
} 
Jestliže bychom přijali pohled Eisgrubera a Sagera, mohli bychom připustit, že náboženská svoboda a její ochrana jsou pozůstatky dob, kdy lidé vedli války z náboženských důvodů. Podle Finnise tito dva autoři nakládají s náboženstvím takovým způsobem, jako by bylo naprosto neschopné poskytnout jakékoli porozumění nebo racionální odpovědi ve vztahu k jakémukoli aspektu reality. ${ }^{18}$

Znamená to, že náboženství má podle Eisgrubera a Sagera zásadně emocionální charakter a tito autoři nejsou schopni připustit, že náboženská volba může být výsledkem racionálního úsudku, který vede člověka k uznání existence transcendentálního inteligentního stvořitele. Odmítají tedy myšlenku ,inteligentního projektu“ a nejsou schopni připustit, že obecná hypotéza inteligentního projektu celého vesmíru (včetně všech vědecky potvrzených mechanismů evoluce) je jedním z racionálních základů náboženské víry. ${ }^{19}$

Finnis tvrdí, že oba autoři chápou svědomí člověka výlučně v kategoriích věrnosti sobě samému a vlastní autentičnosti. Podle Finnise se ale otázky svědomí vztahují ke kategorii pravdy. V něco věřit znamená tvrdit, že obsah př́slušného úsudku svědomí je pravdivý. Zpronevěření se tomuto úsudku je proto jednáním proti pravdě a morálce. Změna názoru znamená jedině to, že daná osoba dřive chybovala $\mathrm{v}$ tom, co považovala za pravdu. Finnis se zároveň pečlivě snaží vyhnout možnému obvinění ze subjektivismu. Klade důraz na to, že jednání v souladu se svědomím není možné zaměňovat za věrnost sobě samému, protože ztotožnění těchto dvou stavů by vedlo k negaci smyslu pro pokání. ${ }^{20}$

Podobně podle Finnise nelze klást na stejnou úroveň náboženství na jedné straně a přesvědčení ve svědomí člověka a autonomní spoluúčast na straně druhé, nezávisle na tom, jak hluboké by toto přesvědčení bylo. Autonomní spoluúčast může být horlivá až vášnivá v tom smyslu, že pocit vášně může být iracionální a může vyžadovat podřízení pravidlům rozumu. ${ }^{21}$

Finnisovy argumenty lze považovat za přesvědčivé, pokud přijmeme jeho rozhraničení role rozumu a pocitů v rámci motivace a etického usuzování. Už od 18. století tato otázka vzbuzuje neustále diskuse. První proud staví na první místo roli rozumu, zatímco druhý (reprezentovaný především Davidem Humem) zdůrazňuje roli vášní v morálním rozhodování. ${ }^{22}$

Podle Finnise je zájem o otázku svědomí úctyhodný jen tehdy, pokud se vztahuje k zájmu o pravdu. Následně zájem o náboženské svědomí může mít význam jen za předpokladu, že některé $\mathrm{z}$ úsudků $\mathrm{v}$ náboženských záležitostech mohou být pravdivé. ${ }^{23}$ Finnis zastává odlišný názor než Brian Leiter, který tvrdí, že náboženské přesvědčení je nemožné zdůvodnit, jelikož má úplně jiný logický status než věda, což ukazuje na jeho podřazené postavení. ${ }^{24}$

K tomuto tématu se Finnis vyjadřuje následujícím způsobem: „Jedna z nejdůležitějších pravd týkajících se náboženských otázek je ta, že božská kreativita a inteligence se nachází u samotného zdroje pravdy a především schopnosti člověka formulovat úsudky, které jsou přinejmenším občas pravdivé a proto jej spojují s minulými i současnými reáliemi stejně jako se skutečnými možnostmi jeho individuálního i společenského rozvoje. Největší význam náboženství pro lidský život a lidský blahobyt spočívá v tom, že vyjadřuje více méně pravdu o

\footnotetext{
18 FINNIS, J. Why Religious Liberty is a Special, Important and Limited Right. Notre Dame Legal Studies Paper No. 09-11, 2008, s. 6.

19 Tamtéž, s. 6.

20 FINNIS, J. Why Religious Liberty is a Special, Important and Limited Right. Notre Dame Legal Studies Paper No. 09-11, 2008, s. 8.

21 Tamtéž, s. 8.

22 MACKIE, J. L. Hume's Moral Theory, London: Routledge, 1980, s. 7 a násl.

23 FINNIS, J. Why Religious Liberty is a Special, Important and Limited Right. Notre Dame Legal Studies Paper No. 09-11, 2008, s. 8.

24 LEITER, B. Why Tolerate Religion? New Jersey: Princeton University Press, 2013, s. 59.
} 
pravdě (tedy v důsledku také o svědomí). Taková pravda o pravdě v konečném důsledku směřuje k vůli Stvořitele, jehož existence poskytuje vysvětlení, které zkoumající lidský rozum vyžaduje. “25

\section{PŘIROZENÉ NÁBOŽENSTVÍ}

Finnisova argumentace na jedné straně vede ke zdůraznění role náboženství při vytvoření opory jak pro lidský život, tak také pro poznávací aktivity. Na druhé straně Finnis stojí pevně na základech teistické vize náboženství, která zdůrazňuje roli Boha Stvořitele. Různé náboženské koncepce pak mají menší nebo větší hodnotu v závislosti na tom, jak daleko se nacházejí od této vize. Takový přístup je v současnosti obtížně akceptovatelný, jelikož rozděluje náboženství na vyšší (odvolávající se na osobu Stvořitele) a nižší (například polyteistické nebo animistické). Neuznává tak rozmanitost způsobů pojetí posvátnosti a pluralitu náboženských prožitků.

Finnis tedy vychází jednoznačně z židovsko-křest’anského pojetí náboženství, což může být problematické z hlediska možného zpochybnění jejich rovnosti, na níž je postaven článek 9 Evropské úmluvy o lidských právech nebo článek 18 Mezinárodního paktu o občanských a politických právech. $\mathrm{V}$ důsledku to pak může znamenat určité omezení náboženské svobody. Navíc toto pojetí marginalizuje existenci náboženských koncepcí, které nepoužívají kategorii „nejvyšší bytosti“. Finnis je označuje jako „neparadigmatické, více méně rozředěné př́klady náboženství", i když si zároveň všímá, že některé z nich (jako budhismus) byly velmi významné $\mathrm{z}$ historického hlediska. ${ }^{26}$

Stojí za pozornost, že v úvahách o náboženské svobodě Finnis klade důraz na určitý druh náboženství, což nedělá ve své teorii přirozeného práva, kde přiznává náboženství v obecném smyslu místo mezi základními hodnotami a tím jeho teorie získává daleko univerzálnější charakter. Takovou univerzálnost bychom marně hledali ve Finnisově pojetí náboženské svobody. Je možné, že nezachoval koncepci obsaženou v knize Přirozené právo a přirozená práva z toho důvodu, že by se tím př́liš přiblížil egalitárním koncepcím náboženské svobody, které byly objektem jeho kritiky.

Vymezení „Nejvyšší bytosti - Stvořitele“ jako ústředního pojmu náboženství, který vystupuje ve všech ,paradigmatických“ náboženstvích, vede Finnise k tvrzení, že odvolání se na „přirozené náboženství“ a víru ve Stvořitele je ve veřejném prostoru naprosto oprávněné a nijak nenarušuje náboženskou svobodu, ale naopak ji posiluje. Dodává také, že „,přirozené náboženstvi'“ podporuje ideu rovnosti všech lidí, která zdůrazňuje hodnotu každého jednotlivce jako lidské bytosti. ${ }^{27}$

Finnis odmítl jako nesprávné rozhodnutí Nejvyššího soudu USA ve věci Engel v. Vitale ${ }^{28}$, které označilo za protiústavní modlitbu ke Stvořiteli ${ }^{29}$ ve veřejných školách, dokonce i když není povinná. Na druhé straně souhlasí s názorem Gerarda Bradleyho, který poukazuje na to, že koncepce ,přirozeného náboženství“ měla velký význam pro otce zakladatele již při samotném vzniku USA. ${ }^{30}$ Tato koncepce se stala populární díky představitelům skotského osvícenství, kteří ji chápali jako formu nekonfesního zobecnění křest’anství smíseného s prvky stoické filozofie, které má být základem rozvinuté morální teorie. V této teorii zaujímala důležité místo

25 FINNIS, J. Why Religious Liberty is a Special, Important and Limited Right. Notre Dame Legal Studies Paper No. 09-11, 2008, s. 9.

26 FINNIS, J. Why Religious Liberty is a Special, Important and Limited Right. Notre Dame Legal Studies Paper No. 09-11, 2008, s. 10

27 Tamtéž, s. 10.

28 Engel v. Vitale, 370 U.S. 421 (1962).

29 Almighty God, we acknowledge our dependence upon Thee, and we beg Thy blessings upon us, our parents, our teachers and our country. Amen.

30 BRADLEY, G. V. Religious Liberty in the American Republic, Washington: The Heritage Foundation, 2008, s. 8-46. 
přirozená práva, která bylo potřeba o něco opřít. Tuto funkci plnilo právě „,přirozené náboženství'. 31

Nelze se asi divit roli, kterou přirozené náboženství hrálo při založení USA, kdy mělo integrovat vše, co spojovalo tehdejší obyvatele, nezávisle na konfesních rozdílech. Těžko si lze ale představit, že by přirozené náboženství mohlo stejnou funkci plnit v současných pluralitních společnostech v rámci euroamerické civilizace. Odvolávání se na přirozené náboženství se může jevit jako určitý relikt dávných časů. Pro někoho jiného to může znamenat zastřený pokus o prosazení křest'anství veřejnou mocí, což představuje potenciální zdroj různých konfliktů.

\section{STŘET CIVILIZACÍ}

Finnis se věnoval také vymezení hranic náboženské svobody v souvislosti s islamistickým terorismem. Vyjádřil se především skepticky k možnosti přizpůsobení islámu hodnotám euroamerických právních systémů. Souhlasně cituje z rozhodnutí Evropského soudu pro lidská práva ve věci Refah Partisi and Others v. Turkey z roku 2003, ve kterém tento soud potvrdil výrok sedmičlenného senátu z roku 2001, že rozpuštění turecké Strany prosperity bylo v souladu s Evropskou úmluvou o lidských právech.

Soud ve shodě s tureckým Ústavním soudem uznal, že šaría, která věrně odráží náboženská dogmata a pravidla, má stabilní a neměnný charakter. Jsou jí cizí takové principy jako pluralismus v politické účasti nebo neustálý rozvoj veřejných svobod. Soud poznamenal, že jsou-li inkriminovaná prohlášení, která obsahují explicitní odkazy na nastolení šaríi, čtena společně, jsou jen těžko slučitelná se základními principy demokracie, tak jak vyplývají z Úmluvy jakožto celku. $^{32}$

Stěží lze zároveň hlásat úctu $\mathrm{k}$ demokracii a lidským právům a podporovat režim založený na šarii, který se jasně odklání od hodnot Úmluvy, zejména s ohledem na svá pravidla trestního práva a trestního řízení, dále na místo, jaké v právním řádu vykazuje ženám, a konečně na své zasahování do všech oblastí soukromého a veřejného života v souladu s náboženskými normami. Kromě toho prohlášení, jež se týkají přání ustavit "spravedlivý řád" nebo "řád spravedlnosti" či "božský řád", i když mohou být interpretována různě, jejich společným jmenovatelem je, jsou-li čtena v souvislostech, že odkazují na náboženská pravidla, pokud jde o politický režim chtěný řečníky. Prozrazují dvojsmyslnost, pokud jde o oddanost jejich autorů každému řádu, který není založen na náboženských pravidlech. Proto podle Soudu politická strana, jejíž činnost se zdá směřovat k nastolení šaríi ve státě, který je smluvní stranou Úmluvy, může být stěží pokládána za sdružení jsoucí v souladu s demokratickým ideálem, na němž stojí celá Úmluva. ${ }^{33}$

Finnis označuje zákaz podobných náboženských stran za „preventivní obranu demokracie“. Upozorn̆uje na to, že islámská politická uskupení mohou aplikovat taktiku označovanou jako takiya, která spočívá ve skrývání skutečných cílů do momentu, kdy už jejich realizaci nelze zabránit. Podle něj není třeba čekat na odkrytí skutečných cílů, ale stačí nahlédnout do skutečných dokumentů. Jedním z nich je například káhirská Deklarace práv člověka $\mathrm{v}$ islámu z roku 1990. Ta je kritizována zejména pro nábožensky jednostranný pohled, kdy se řada bodů deklarace přímo odkazuje na šaríu a závěrečné dva body ji výslovně uvádí jako autoritu a jediný zdroj pro výklad či vysvětlení jednotlivých bodů deklarace. Náboženskou svobodu omezuje

31 BROADIE, A. Scottish Enlightenment. An Anthology. Edinburgh: Canongate, 1997, s. 356 a násl.

32 Refah Partisi (Strana prosperity) proti Turecku, rozsudek z 31. 7. 2001, stížnosti č. 41340/98, 41342/98, $41343 / 98$ a 41344/98.

33 Refah Partisi (Strana prosperity) proti Turecku, rozsudek z 31. 7. 2001, stížnosti č. 41340/98, 41342/98, 41343/98 a 41344/98. 
v čl. 10, kde se říká: „Islám je náboženství skutečné nezkažené přirozenosti. Je zakázáno využívat jakékoli formy nátlaku na člověka nebo zneužívat jeho chudoby a nevzdělanosti k tomu, aby př̌šel od jednoho náboženství $\mathrm{k}$ druhému nebo $\mathrm{k}$ ateismu. “34

Finnis jasně zdůrazňuje, že islám není slučitelný s hodnotami euroamerické civilizace a jejím pojetím náboženské svobody. Upozorňuje, že teologické základy islámu obsahují politický koncept, který je neslučitelný s ústavními principy, které jsou v euroamerické civilizaci uznávány za východisko platného práva. Klade si několik otázek: Je protiústavní diskriminovat z náboženských důvodů na hranicích státu? Znevažuje takové jednání vyznavače tohoto náboženství, kteří už jsou občany daného státu? Omezuje to jejich náboženskou svobodu? Anebo náboženskou svobodu těch, kteří nebudou vpuštěni na území státu v zájmu veřejného pořádku a bezpečnosti? ${ }^{35}$

Podle všeobecného mínění stát nemá vstupovat do náboženských záležitostí. Nicméně ohrožení ze strany fundamentalistického pojetí islámu vyžaduje přehodnocení takového stanoviska. Finnis souhlasí s politikou vlád v Německu, Francii nebo Velké Británii, které se snaží podporovat umírněnou verzi islámu prostřednictvím výběru náboženských učenců a kontroly toho, co hlásají. Situace v Evropě ukazuje, že existuje veřejný zájem na tom, aby toto náboženství a jeho vyznavači nebyli ponecháni vlastnímu osudu. Finnis tak zároveň zpochybňuje ideu „oddělující zdi“, která charakterizuje model vztahu mezi státem a náboženstvími v USA, jelikož je podle něj nepřiměřená současnému ohrožení ze strany islamistického fundamentalismu. Oslabení této hrozby vyžaduje aktivní zásahy státu směrem $\mathrm{k}$ podpoře umírněného islámu. ${ }^{36}$

\section{ZÁVĚR}

Finnisovy názory mají zjevně konzervativní nádech. Zdá se, že jeho cílem je zdůvodnění zvláštního významu monoteistických náboženství, které obsahují pojem Boha Stvořitele. Je třeba ovšem poznamenat, že jeho teorie přirozeného práva vychází z odlišného pojetí náboženství jako základní hodnoty chápané velmi široce a neortodoxně.

Zároveň ale Finnis zdůrazňuje, že náboženská svoboda nemůže být vnímána jako neomezená. Je třeba ji skloubit se zajištěním veřejného pořádku, spravedlnosti a veřejné morálky. Správné pochopení těchto neurčitých pojmů může vést $\mathrm{k}$ adekvátnímu omezení náboženské svobody v časech, kdy své požadavky vznášejí různé menšinové společenské skupiny a setkáváme se s nábožensky motivovaným terorismem. ${ }^{37}$

\section{KLÍČOVÁ SLOVA}

Přirozené právo, Bůh, náboženství, náboženská svoboda, islám

\section{KEY WORDS}

Natural law, God, religion, religious freedom, islam

\section{POUŽITÁ LITERATURA}

1. BRADLEY, G. V. Religious Liberty in the American Republic, Washington: The Heritage Foundation, 2008

\footnotetext{
34 THE CAIRO DECLARATION ON HUMAN RIGHTS IN ISLAM - https://app.icrc.org/elearning/ understanding-detention/story_content/ external_files/Human\%20Rights\%20in\%20Islam\%20(1990).pdf

35 FINNIS, J. Why Religious Liberty is a Special, Important and Limited Right. Notre Dame Legal Studies Paper No. 09-11, 2008, s. 16.

36 Tamtéž, s. 17.

37 Tamtéž, s. 13.
} 
2. BROADIE, A. Scottish Enlightenment. An Anthology. Edinburgh: Canongate, 1997

3. EISGRUBER, Ch., Sager, L. Religious Freedom and the Constitution, Harvard University Press, 2007. Dostupné na https://doi.org/10.4159/9780674034457.

4. FINNIS, J. Natural Law and Natural Rights, Oxford: Oxford University Press, 1980

5. FINNIS, J. Religion and Public Reason, New York: Oxford University Press, 2011. Dostupné na https://doi.org/10.1093/acprof:oso/9780199580095.001.0001.

6. FINNIS, J. Why Religious Liberty is a Special, Important and Limited Right. Notre Dame Legal Studies Paper No. 09-11, 2008. Dostupné na https://doi.org/10.2139/ssrn.1392278.

7. GEORGE, R. In Defence of Natural Law, New York: Oxford University Press, 2004

8. GRISEZ, G. Natural Law, God, Religion and Human Fulfillment, American Journal of Jurisprudence, Vol. 46, 2001. Dostupné na https://doi.org/10.1093/ajj/46.1.3.

9. GRISEZ, G., BOYLE, J., FINNIS, J.: Practical Principles, Moral Truth and Ultimate Ends, The American Journal of Jurisprudence, Vol. 32, 1987. Dostupné na https://doi.org/10.1093/ajj/32.1.99.

10. KAVENY, C. Ethics at the Edges of Law: Christian Moralists and American Legal Thought, New York: Oxford University Press, 2017. Dostupné na https://doi.org/10.1093/oso/9780190612290.001.0001.

11. KŘÍŽ, J. Autonomie církví, Praha: C. H. Beck, 2017

12. LEITER, B. Why Tolerate Religion? New Jersey: Princeton University Press, 2013. Dostupné na https://doi.org/10.23943/princeton/9780691163543.003.0004.

13. MACKIE, J. L. Hume's Moral Theory, London: Routledge, 1980. Dostupné na https://doi.org/10.4324/9780203359891.

\section{KONTAKTNÍ ÚDAJE AUTORA}

JUDr. Petr Osina, Ph.D.

Odborný asistent

Právnická fakulta Univerzity Palackého

Katedra teorie práva a právních dějin

tř. 17. listopadu 8

Olomouc 77111

Česká republika

Telefon: +420 585637611

Email: petr.osina@upol.cz 